\title{
THE STABILIZATION EFFECTS OF FISCAL POLICY ON BANKING SYSTEM STABILITY IN NIGERIA
}

\section{Agatha Nkem AMADI ${ }^{1+}$ \\ Kehinde Adekunle ADETILOYE ${ }^{2}$ \\ Alexander \\ Ehimare \\ OMANKHANLEN ${ }^{3}$ \\ (D) Idimmachi Pius \\ AMADI ${ }^{4}$ \\ Pascal \\ NWODIMMAH}

Article History

Received: 29 July 2021

Revised: 6 September 2021

Accepted: 27 September 2021

Published: 22 October 2021

\section{Keywords}

Banking system stability Taxation policy

Debt

Government expenditure

Treasury single account

Consumption tax.

JEL Classification:

G10; G20; H30; H62.
${ }^{\prime}$ Department of Banking $E^{2}$ Finance College of Business and Social Sciences Covenant University Ota, Ogun State, Nigeria.

'Email:agatha.amadipgs@stu.cu.edu.ng Tel: +(234)9069320790

${ }^{2,3,5}$ Department of Banking and Finance, Covenant University, Nigeria.

${ }^{2}$ Email: kehinde.adetiloye@covenantuniversity.edu.ng Tel: +(234)8022959065

${ }^{3}$ Email: alexander.omankhanlen@covenantuniversity.edu.ng Tel: +(234)8034282063

${ }^{5}$ Email: pascal.nwodimmah@stu.cu.edu.ng Tel: +(234)7030427411

${ }^{4}$ Department of Economics and Development Studies, Covenant University,

Nigeria.

${ }^{4}$ Email:idimmachi.amadi@stu.cu.edu.ng Tel: +(234)8027750883

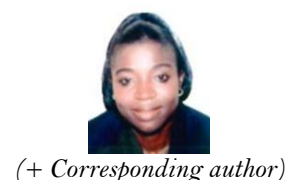

(+ Corresponding author)

\section{ABSTRACT}

This study examined the stabilization effect of fiscal policy on banking system stability in Nigeria using data from 1985 to 2019 . The study adopted the ordinary least squares, cointegration and error correction techniques to analyze and determine the existence of a long-run relationship among the variables. The ordinary least squares technique was used to evaluate the impact of the interaction between fiscal policy and banking system stability variables. The findings indicate that fiscal policy has a strong influence on banking system stability in Nigeria. It was further discovered that, among the fiscal policy variables, taxation and government debt have a more positive effect on banking systems than other variables used in the study, while government funding and debt growth have a negative effect on banking system stability. This indicates that the more debt the government accumulates, the greater the instability of the banking system. The study recommends that the government put appropriate controls in place to avoid borrowing that will creep into deficit, which will, in turn, affect the banking system stability. The government should also ensure that its borrowings are channeled into productive segments of the economy to enhance the sustainable repayment of debt and ensure that the mechanisms for debt repayment are strictly adhered to.

Contribution/Originality: This study contributes to the existing literature on the fiscal sector effects on banking system stability by clearly showing the channels through which this can happen. The basic channels of effect are through tax (collection and expenditure, public debt and its growth rate). This study adds to the few existing literature and extends the frontlines of knowledge by examining the links among fiscal policy and banking system stability.

\section{INTRODUCTION}

The direct effect of the use of fiscal policies that affect the banking system, especially with public sector funds such as the Treasury Single Account (TSA), often created panic in the banking industry, such that another round of crises in the banking system might be anticipated. This was because of the heavy reliance and dependence of the Nigerian economy on public sector funding, for which the government has total power to distribute resources. 
Equally, the 2007 global financial crisis that started in the United States had detrimental effects on the growth of many economies (Alqahtani \& Mayes, 2018; Knowles, Phillips, \& Lidberg, 2017) causing a retraction and reduction in global capital flows. The banking system, being a vector and at the center of the financial system, experienced diverse challenges that led to the liquidation of some banks, as many operated-on fringe and marginal bases. According to Dumičić (2019), fiscal policy has some vast macro-prudential potentials because of its linkages with both the real economy and the financial systems. For example, tax policies, public expenditure, public debt management, different structural measures and other fiscal policy measures are normally aimed at fuelling higher levels of employment and sustainable economic growth. Adegoriola (2018) opined that fiscal policy is a critical part of the post-crisis framework for macro-financial stability. The study revealed further that banking crises could cause havoc to public finances just as rising fiscal risks could directly or indirectly cause deterioration of the financial system.

Nigeria's fiscal policy has been used solely for economic purposes - to amass and aggregate resources for government expenditure. The banking system has been affected by these stabilization policies since the 1970 s mainly due to (i) the dominant roles the domestic public sector played during the oil boom era in early 1970 s and 1980s, (ii) the necessity to reconstruct the whole economy after the civil war, and (iii) the strategy of industrialization adopted at a time during which Nigeria was under military rule with its flawed import substitution industrialization strategy (Agu, Okwo, Ugwunta, \& Idike, 2015). It is an undisputable fact that fiscal policy is crucial for the existence of a sound and healthy banking system because the government's control of taxation and expenditure affects the general business environment and the disposable income of citizens and corporations that aid banking system stability. Despite the undisputable relevance of fiscal policy for curbing economic instability and preserving banking system stability, there are currently no prior studies on the coordination between fiscal policies and banking system stability in Nigeria and no study exists on concurrent fiscal policy with its effects aimed at stabilizing Nigeria’s banking system.

Earlier empirical studies are imprecise about whether or not any of the tools of government fiscal policy matter in decoupling the banking system stability in Nigeria. For instance, Tule, Onipede, \& Ebuh (2020) extensively discussed the fiscal and monetary policy mix on development and growth in Nigeria. This type of study has not been extended to the banking sector or its stability. The counter-cyclical fiscal policy reaction to banking system stability is one possible channel through which normalcy can be restored. However, in the empirical literature, less attention has been given to its effects on banking systems globally, particularly in emerging countries such as Nigeria, which has witnessed frequent banking system crises that were caused by both domestic and global shocks thus making it difficult for the government to adjust its fiscal expenditure during adverse periods of shocks in the short run. Consequently, not only is this study timely and necessary, but it is also central in decoupling the banking system stability linkages through fiscal policy response tools. Furthermore, the rationale for this study becomes important as the banking system in Nigeria is faced with persistent and large shocks that have resulted from global financial crises, the uncertainty of oil prices, and the implementation of counter-cyclical fiscal policies to boost economic activities. Subsequently, the main goal of this study is to analyze the effects of fiscal policy variables on banking system stability. Indisputably, fiscal policy is crucial for the existence of a sound and healthy banking system because government's control of tax and expenditure affects the general business environment and the disposable income of citizens and corporations which aids banking system stability. This study adds to the existing literature in three ways. First, this study applies broad measures of fiscal policy tools on banking system stability. Second, the importance of the link between fiscal policy tools and banking system stability in Nigeria is analyzed, and last, an econometric model is used to examine the macro data in order to provide appropriate policy direction for the management of the banks, financial system regulators and the government. 
The paper comprises five sections. Following this section is the literature review; sections three and four represent the methodology and empirical analysis, respectively; and section five contains the conclusion and recommendations.

\section{LITERATURE REVIEW}

\subsection{Conceptual Review}

2.1.1. Fiscal Policy

According to Ubi-Abai \& Bosco (2017), fiscal policy is defined as an intervention tool used by the government via expenditure and the tax system for the achievement of macro-economic goals, such as full employment, price stability and economic growth. The automatic stabilizers are a set of fiscal policy instruments designed to offset variations in a country's economic activities through normal operations without additional legislative approval by the policymakers or government. Automatic stabilizers are those policies that stabilize economic cycles and financial systems and are routinely triggered without extra government action. For instance, during a boom, tax receipts automatically increase and expenditure on benefits falls automatically, thereby limiting the amount of economic growth. Automatic fiscal stabilizers differ from discretionary fiscal policy in that automatic stabilizers take place during recessions when governments spend more of its resources on additional claims and the need to incentivize growth. However, the government may increase expenditure if it discovers that the automatic stabilizers are not sufficient to achieve the desired outcomes.

\subsubsection{Banking System Stability}

The Basel Committee on banking supervision established an initial set of guidelines (Basel I) to complement banking regulations to improve the stability of the banking system and to fill the synchronization gap that led to prior financial crises. It was, however, discovered that Basel I was ineffective owing to rapid financial development caused by innovation and risk management. Basel II was subsequently developed in 2004, which was based on three pillars: supervisory review, market discipline and minimum capital requirement. The implementation of the Basel II framework was both slow and difficult. Then, the 2007-2010 global financial crisis had a massive impact on global banking system stability. The unpredictable business environment characterized by increased financial distresses and bank failures required that immediate attention be paid to the banking system in particular and other financial institution in general. Many issues were raised, and due to the impact that they had on the economies the desire to solved the problems became top priority for financial experts, academics, policy makers and researchers. This led the Basel Committee on banking and supervision to implement another novel framework for banking supervision, which was established after serious re-examination of the previous banking regulatory frameworks - Basel I and II - and especially the immediate impact of the global financial crisis that led to the Basel III framework. A major disruption of banking system operations will certainly affect the entire economy and society. Thus, banking stability is critical to reducing the extensive social and economic shocks that may arise from instability to the banking system (Neem, 2019).

\subsubsection{The Relationship between Fiscal Policies and the Banking System}

The fiscal policies of the governments (local, state and federal) have a direct link with the banking system when their fiscal deficits are financed and their debts are managed. This direct relationship stems from government participating as a borrower or lender in the financial markets, offering incentives through tax and tax cuts, as well as managing spending structures. Similarly, the indirect relationship between fiscal policy and the banking system through households and non-financial corporations are broad and highly relevant. This indirect link may be more relevant to banking system stability than the direct links. Fiscal policy could signify a risk to banking stability if it poses a risk for the operations of the real economy. Nevertheless, fiscal policy contributes positively to banking 
system stability as long as it supports overall economic developments. Furthermore, the concept of the direct and indirect linkage between fiscal policy and banking system stability may depend mainly on the financial capacity of the government, which is, in turn, influenced by the size of accepted and contingent government support already provided to the banking system (Itoro, 2017; Okoye, Evbuomwan, Modebe, \& Ezeji, 2016). Figure 1 shows how the main elements of fiscal policy can be effective in the stabilization of the banking system with the main instruments of public debt, external debt, consumption tax, government funding (transfers) and expenditure.

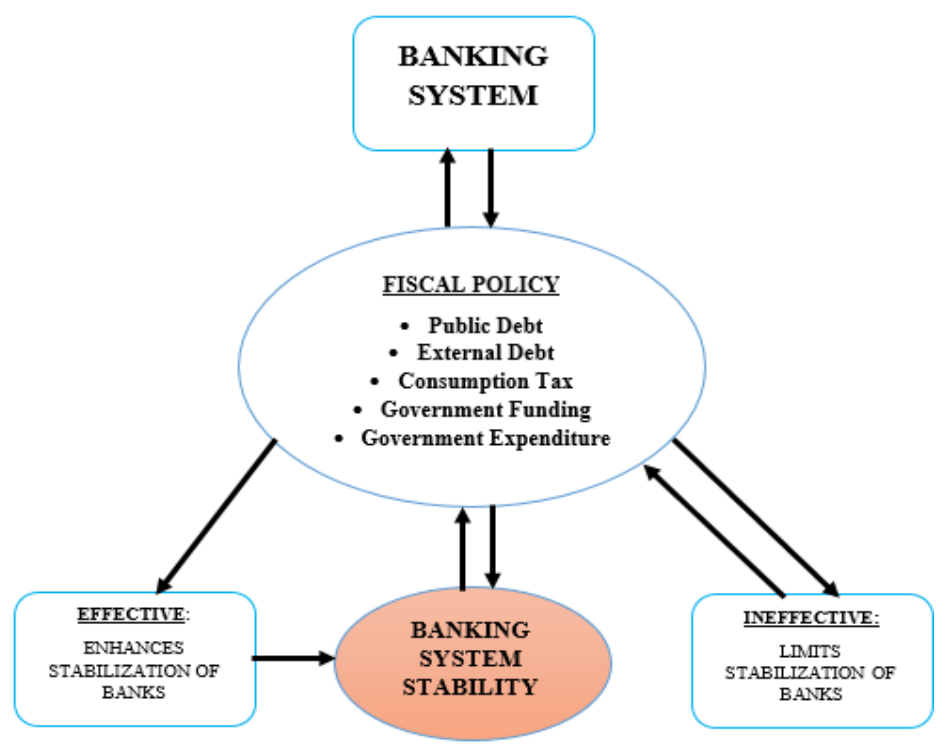

Figure 1. Banking System Interaction with the Fiscal Sector.

\subsection{Framework}

\subsubsection{Stylized Facts}

According to Okoye et al. (2016), fiscal policy is defined by studies as a channel through which government regulates the level of its spending to monitor the impact on the economy. While fiscal policies are used alongside the monetary policy the central bank influence on money supply in a country becomes stronger. These policies are used to achieve macroeconomic goals, which include a favourable balance of payment, price stability, a decrease in poverty level, full employment, a reduction in a country's debt, and sustainable economic growth. Government spending is a key component of GDP, and it denotes public expenditure on goods and services. It is among the many fiscal policy tools, which involves adjustment of taxation and setting up budget targets.

In alignment with a previous study, an increase was seen in government spending, from 1,077,871.98 million $(\$ 2,628.96$ million) in the third quarter of 2019 to $\$ 1,082,949.34$ million (\$2,641.34 million) in the last quarter of 2019. Increased government spending impacts positively on banks' performance, which benefits banking system stability because more funds will pass through the banks to the end users - the consumers. For instance, the effect of government engagement in banking services for the economy expanded the total cash flow in and out of the banking system. Similarly, it was found that there was a decrease in fiscal expenditure from $\$ 2,074.46$ billion ( $\$ 5.06$ billion) in the third quarter of 2019 to $\$ 2,414.03$ (\$5.88) billion in the fourth quarter of 2019 (Trading Economics, 2020).

\subsubsection{Empirical Review}

As indicated in earlier studies by Matallah \& Matallah (2017), Okoye et al. (2016) and Aero \& Ogundipe (2018), fiscal policy involves deliberate actions of the government related to expenditure and levying or cutting taxes for 
the sake of influencing the macroeconomic factors in the preferred direction. The importance of fiscal policy tools with regard to banking system stability is yet to gain prominence in Nigeria (Neem, 2019). In this section, this study discusses numerous strands of previous literature. This includes Okoye et al. (2016) and Agu et al. (2015), who focused on fiscal policy and economic growth. Thach, Oanh, \& Chuong (2018), Adegoriola (2018), and UbiAbai \& Bosco (2017) analyzed the nexus between fiscal policy and financial stability, whereas Dumičić (2019) studied the linkages between fiscal policy and financial instability.

Regarding the studies that focus on fiscal policy and economic growth, Aero \& Ogundipe (2018) confirmed the existence of a significant negative link among fiscal deficits, economic growth and financial depth in Nigeria. In addition, a 5\% threshold level was established; this is said to be a conducive level for economic growth at a one-year lag. It therefore resolved that the economy have been categorized by constant fiscal deficits that has negative influence on economic growth. Similarly, Neem (2019) focused on ten countries between the 2002 and 2014 , and after adopting a dynamic panel ARDL technique, the results showed that fiscal policy is a basic instrument for economic growth.

Dumičić (2019) examined the relationship between fiscal policy and financial instability. The study ascertained and defined the key channels by which fiscal policy is related to financial instability. The study explored numerous features of public debt that are linked to financial stability, which include the government's funding costs and their effect on the private sector costs of funding, exposure of financial institutions to the government, and sustainability of public debt management. The study found that fiscal policies that related to election cycles have different time horizons for different policymakers with their peculiar problems. Thus, there is a negative effect on the countercyclical capacity in those countries. It further revealed that for future policy work and research, the macro prudential capability of fiscal policy could attract further attention.

Ubi-Abai \& Bosco (2017) focused on the effect of fiscal policy measures on key macroeconomic goals in Nigeria from 1980 to 2013. The results showed that fiscal policies caused increased growth in output; however, the longrun impact was not effective. Furthermore, Thach et al. (2018) discussed the impacts that the interaction between fiscal and macro-prudential policies had on financial stability in Vietnam from 2008 to 2009, and the result revealed that fiscal and macro-prudential policies had a great influence on financial stability.

Agu et al. (2015) analyzed the influence of several fiscal policy tools on the Nigerian economy. The result showed that aggregate government expenditures increased with government revenue, but revenue increased more slowly than expenditure, indicating poor economic growth. It also found that a positive correlation exists between government expenditure and economic growth. Alińska (2016) established that fiscal policy is a critical measure of the post-crisis macro-financial stability framework. The study confirmed that the banking system crisis caused a distraction from public finances, and the increased fiscal risks led to the decline of the financial system. The result also showed that a resilient countercyclical standpoint could help to cope with the excess growth of asset prices and credit.

From the literature reviewed, it is apparent that quite a number of scholars have shed light on the nexus between fiscal policy and economic growth (see Matallah \& Matallah (2017); Neem (2019)), with others focusing on the linkages between fiscal policy and financial stability (e.g., Adegoriola (2018); Thach et al. (2018); Ubi-Abai \& Bosco (2017)). The effect of fiscal policy on banking system stability has been omitted in most discussions in previous studies. Moreover, the fact that fiscal policy tools are crucial to the stabilization of banking systems in developing economies such as Nigeria, therefore, their effect on general banking system stability cannot be overlooked. In addition, at the time of this study, very little prior literature existed on fiscal policy and banking system stability in Nigeria despite its relevance. Thus, this study tests the effect of fiscal policy tools (government expenditure, external debt, government funding, public debt and consumption tax) on banking system stability. Furthermore, this study includes consumption tax instead of value added tax in the model, as this has been omitted in most existing studies. The inclusion of consumption tax in the model is due to its effect on the purchasing power 
of the citizens. The higher the consumption tax, the lower the amount available to purchase more goods and the lower the savings ability thus reducing the purchasing power of consumers. This study indicates a dearth in literature, particularly regarding Nigeria's banking system, and hence offers an important contribution.

\section{RESEARCH METHODOLOGY}

\subsection{Theoretical Framework}

In an effort to highlight the theoretical basis for the explicit relationship, between fiscal policy and banking system stability, this current study is theoretically underpinned to Keynesian economics theory that was developed in the 1930s. Keynes established the theory in an effort to comprehend the Great Depression. It is an economic theory that explains the effect of aggregate expenditure on inflation and output in an economy, and it is also a 'demand-side' theory that centers on economic changes over a short-run period. The theory established that in order to stimulate demand and bring the world economies out of the depression, the governments must increase their spending (expenditure) and reduce taxes (tax cuts). The Keynesian economics theory is a concept which explicitly explained the possibility of achieving optimum economic performance while preventing economic crash by influencing total demand via economic intervention and activist stabilization policies. Thus, as the economies and financial institutions are stabilized via effective implementation of appropriate fiscal policies, the banking system, which is the center point of the financial institutions, will also be stabilized.

\subsection{Model Specification}

The methodical framework adopted for this study follows the Keynesian framework adapted from Chukwudi \& Henry (2020). In the Keynesian framework, a preferred aggregate demand link is stated in the goods market, as specified in Equation 1 below:

$$
Y=C+I+G+(X-M)
$$

Where:

Y represents aggregate output at a specific period of time, $\mathrm{C}$ is total consumption, I indicates total investment, $\mathrm{G}$ is aggregate government expenditure, and $(\mathrm{X}-\mathrm{M})$ represents net exports. Output could be influenced by its own past level in a time series setting and, consequently, the model can be extended to the relationship between fiscal policy and banking system stability, as stated below:

$$
B S T_{t}=f\left(C A D F_{t}, D R G_{t}, P D_{t}, G F D_{t}, C T A X_{t}, E X D_{t}, G C E X P_{t}\right.
$$

Equation 2 above states that banking system stability is a function of CADF, DRG PD, CTAX EXD and GCEXP.

$$
B S T_{t}=C A R_{t}
$$

Here, banking system stability is substituted for the capital adequacy ratio:

$$
B S T_{t}=C A R_{t}=f\left(C A D F_{t}, D R G_{t}, P D_{t}, G F D_{t}, C T A X_{t}, E X D_{t}, G C E X P_{t}\right)
$$

Equation 4 combines Equations 2 and 3.

Explicitly, the econometric model is stated as:

$$
\begin{aligned}
& B S T_{t}=\alpha_{0}+\alpha_{1} C A D F_{t}+\alpha_{2} D R G_{t}+\alpha_{3} P D_{t}+a_{4} G F D_{t}+a_{5} C T A X_{t}+\alpha_{6} E X D_{t}+a_{7} G C E X P_{t}+ \\
& \text { et }
\end{aligned}
$$


Equation 5 explains the econometric model with banking system stability. Finally, the adopted model in the analysis is restated as follows:

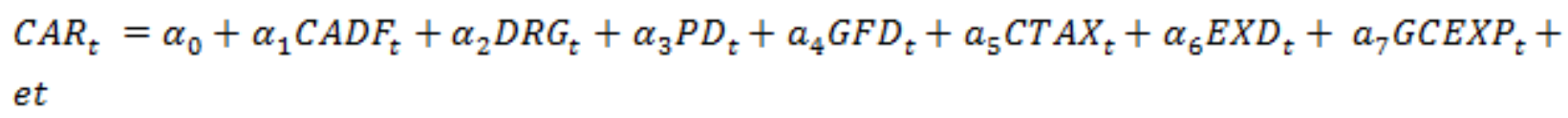

Equation 6 above explains the model to be estimated, where BST represents banking system stability, and the dependent variable is proxied by the bank soundness indicator CAR, which represents the capital adequacy ratio. The independent variables include CADF, which represents current account deficit, DRG is debt growth, PD signifies public debt, GFD is government funding, CTAX represents consumption tax, and EXD signifies external debt. The only control variable in the model is GCEXP, which represents government capital expenditure. The stochastic error term is indicated by $\mathrm{e}_{i} ; \mathrm{t}$ is the time period measured; $\alpha_{0}$ represents the intercept describing banking system stability when the independent variables are equivalent to zero; $\alpha_{1}, \alpha_{2}, \alpha_{3}, \alpha_{4}, \alpha_{5}, \alpha_{6}, \alpha_{7}$ are the parameters or coefficients of the independent variables. The inclusion of the stochastic or error term $\left(e_{t}\right)$ in the above model is to capture the impact of other variables that are not included in the model. Most of the variables were log-transformed to help normalize and linearize the variables, especially those with large figures. The a priori expectations are stated as follows: $\alpha_{1}>0 ; \alpha_{2}>0 ; \alpha_{3}>0 ; \alpha_{4}<0 ; \alpha_{5}<0 ; \alpha_{6}<0 ; \alpha_{7}<0$.

\subsection{Data Sources and Operationalization}

The variables employed in this study are based on several extant works of literature and the theoretical stance of the study discussed above. The data used in the study were sourced from the Central Bank of Nigeria Statistical Bulletin and World Development Indicators and covered the period from 1985 to 2019. This period was chosen due to the availability of data as well as to capture the effect of fiscal policy on the change over the years on the banking system during the various global financial crises and the domestic financial reforms.

The vector error correction model has always been superior to the ordinary least squares method because of the possibility of avoiding a spurious regression and allowing a long-term convergence of variables to be undertaken. It can also produce coefficients from the variables that are more efficient.

Table 1. Summary of ADF unit root test of the model.

\begin{tabular}{c|c|c|c|c}
\hline Variables & P-value I(1) & Critical Values 1\% \& 5\% & ADF t-statistics I $(\mathbf{1})$ & Status \\
\hline CADF & 0.0001 & $-3.646342(-2.954021)$ & -5.257183 & $\mathrm{I}(1)$ \\
\hline CAR & 0.0000 & $-3.646342(-2.954021)$ & -9.255976 & $\mathrm{I}(1)$ \\
\hline LDRG & 0.0027 & $-3.646342(-2.954021)$ & -4.152804 & $\mathrm{I}(1)$ \\
\hline LPD & 0.0000 & $-4.262735(-3.552973)$ & -7.706170 & $\mathrm{I}(1)$ \\
\hline LGFD & 0.0000 & $-4.262735(-3.552973)$ & -7.265155 & $\mathrm{I}(1)$ \\
\hline LGCEXP & 0.0000 & $-3.646342(-2.954021)$ & -8.191326 & $\mathrm{I}(1)$ \\
\hline LEXD & 0.0012 & $-3.724070(-2.986225)$ & -4.625385 & $\mathrm{I}(1)$ \\
\hline LCTAX & 0.0000 & $-4.262735(-3.552973)$ & -7.986416 & $\mathrm{I}(1)$ \\
\hline
\end{tabular}

\subsection{Data Presentation and Analysis}

In this section, the augmented Dickey-Fuller (ADF) unit root test and the inferential analysis of the data are discussed.

Table 1 shows the ADF unit root test results for all the variables and they revealed that the variables became stationary only at first difference. This means that the series are I(1) series. The table shows that the different probability values are less than $1 \%$. 


\subsubsection{Descriptive Data}

The results of the variables show that CAR has the lowest standard deviation (see Table 2). This indicates that the capital increases or decreases are not elastic. The rate of capital injections is rather slow and it can be inferred that the capital erosions are not serious. The highest of the standard deviations is shown by CADF. This indicates that the deficit in the current account is unpredictable and can be either low or high. Table 2 also shows that DRG has a high mean with GFD and government expenditure. The mean of external debt is also high.

Table 2. Summary of descriptive statistics.

\begin{tabular}{c|c|c|c|c|c}
\hline Variable & Mean & Median & Maximum & Minimum & Std. Dev. \\
\hline CADF & 4.151482 & 3.388 & 21.533 & -3.135 & 5.327899 \\
\hline CAR & 0.13943 & 0.160019 & 0.281382 & 0.031008 & 0.061783 \\
\hline LDRG & 13.71585 & 13.71 & 17.18988 & 10.35838 & 2.407603 \\
\hline LCTAX & 4.096823 & 4.133172 & 4.464983 & 3.440174 & 0.268525 \\
\hline LEXD & 8.813061 & 9.076295 & 9.50724 & 7.188866 & 0.620021 \\
\hline LGCEXP & 11.29173 & 11.59876 & 14.9565 & 7.80751 & 2.359398 \\
\hline LGFD & 13.18374 & 12.72686 & 16.92212 & 9.282103 & 2.037326 \\
\hline LPD & 4.827333 & 5.098715 & 7.678499 & 0.473778 & 1.942382 \\
\hline
\end{tabular}

Other computations in the descriptive table show that CADF has a minimum negative figure of -3.135 , indicating that the current account had at one time been negative for the country, while CAR has a low of 35 and a maximum figure of $28 \%$ among the banks. The LCTAX is inelastic, as the maximum figure is 4.46 , while the minimum is 3.44 and the standard deviation (SD) is 0.26 . This implies that the tax growth rate in Nigeria is very low and is more or less static.

Table 3. Johansen's cointegration test.

\begin{tabular}{|c|c|c|c|c|c|c|}
\hline Variable & $\begin{array}{c}\text { Trace } \\
\text { Eigen Statistics }\end{array}$ & $\begin{array}{l}\text { Significance } \\
\text { Level of } 0.05\end{array}$ & P-value & $\begin{array}{l}\text { Maximum } \\
\text { Eigen } \\
\text { Statistics }\end{array}$ & $\begin{array}{c}\text { Significance } \\
\text { Level of } \\
0.05\end{array}$ & P-value \\
\hline None ${ }^{*}$ & 256.7235 & 159.5297 & 0.0000 & 74.08092 & 52.36261 & 0.0001 \\
\hline At most $1^{*}$ & 182.6426 & 125.6154 & 0.0000 & 60.44764 & 46.23142 & 0.0009 \\
\hline At most $2 *$ & 122.1950 & 95.75366 & 0.0002 & 40.98569 & 40.07757 & 0.0394 \\
\hline At most $3 *$ & 81.20928 & 69.81889 & 0.0047 & 29.89419 & 33.87687 & 0.1390 \\
\hline At most $4 *$ & 51.31509 & 47.85613 & 0.0228 & 25.87364 & 27.58434 & 0.0814 \\
\hline At most 5 & 25.44145 & 29.79707 & 0.1463 & 16.84683 & 21.13162 & 0.1793 \\
\hline At most 6 & 8.594620 & 15.49471 & 0.4042 & 6.214213 & 14.26460 & 0.5859 \\
\hline At most 7 & 2.380406 & 3.841466 & 0.1229 & 2.380406 & 3.841466 & 0.1229 \\
\hline
\end{tabular}

Table 4. Long-run estimates.

\begin{tabular}{c|c|c|c|c}
\hline Variable & Coefficient & Std. Error & T-statistic & P-value \\
\hline C & -0.162878 & 0.181269 & -0.898544 & 0.3768 \\
\hline CADF & 0.001723 & 0.001747 & 0.985959 & 0.3329 \\
\hline LDRG & -0.036672 & 0.021363 & $-1.716639 *$ & 0.0975 \\
\hline LCTAX & 0.134118 & 0.065793 & $2.038496 * *$ & 0.0514 \\
\hline LEXD & -0.004116 & 0.017325 & -0.237592 & 0.8140 \\
\hline LGCEXP & 0.033548 & 0.021529 & 1.558250 & 0.1308 \\
\hline LGFD & -0.018488 & 0.007834 & $-2.360004 * *$ & 0.0258 \\
\hline LPD & 0.031050 & 0.009294 & $3.340995^{*} * *$ & 0.0025 \\
\hline R-squared & 0.777304 & Mean dependent variable & 0.139430 & \\
\hline Adj. R-squared & 0.719568 & SD dependent variable & 0.061783 & \\
\hline F-statistic & 13.46307 & Ak info criterion & -3.804178 & \\
\hline Prob (F-statistic) & 0.000000 & Durbin-Watson stat. & 2.043675 &
\end{tabular}

Notes: *, **, and *** indicate levels of significance at $0.10,0.05$, and 0.01 respectively the dependent variable is CAR 
In Table 3, the trace test shows that five co-integrating vectors are present at $5 \%$ critical level while the maxeigen test confirms that three co-integrating equation exist at $5 \%$ critical level. The explanation is that the reject the non-existence of co-integration stand of the null hypothesis and accepts the alternative hypothesis proposition of existence of co-integration in the model. With the output in Table 3 the study discover there at least four cointegrating variables.

Thus, it is considered safe to estimate the data with the vector error correction mechanism for efficient and more reliable results as earlier explained. The study concludes that there exists long-run link between current account deficit, debt growth, public debt, government funding, consumption tax, external debt, government capital expenditure and banking system stability in Nigeria over the period of the study.

\section{REGRESSION RESULT}

Table 4 presents the ordinary least squares results, which indicate that the estimates of the long-run model captures the effect of fiscal policy variables on banking system stability during the period covered by the study. The results show that four variables (current account deficit, consumption tax, government capital expenditure and public debt) have positive and impactful relationships with banking system stability proxied with the bank soundness indicator - capital adequacy ratio. This confirms our a priori expectation for these variables. The remaining three variables (debt growth, external debt and government funding) have a negative impact on banking system stability in Nigeria.

However, only consumption tax and public debt have a positive and significant relationship with capital adequacy ratio, while debt growth (DRG) and government funding have a negative but significant association with capital adequacy ratio. In addition, the results showed that the coefficients of CTAX, PD and GFD, which are $0.134118,0.031050$, and -0.036672, respectively, are significant at 5\%. This indicates that a unit change in CTAX induces a 0.13-unit positive change in CAR, a unit change in PD induces a 0.03-unit positive change in CAR, while a unit change in GFD induces a -0.03-unit negative change in CAR. The coefficient of DRG has a positive and significant impact on CAR, although it is not significant at $5 \%$. CADF and GCEXP have $t$-statistics that show positive and non-significant impacts on CAR. On the other hand, EXD is the only variable that has a coefficient that shows a negative and non-significant impact on CAR. The positive and significant effects of CTAX and PD could be as a result of the impact these policies have on bank customers and the various business sectors which have a direct impact on banks' operations and performance in Nigeria. The $R^{2}$ value of 0.777304 indicates that about $78 \%$ of the dependent variable is jointly explained by the adopted independent variables, i.e., capital adequacy ratio forms a good fit with a variance of 0.22 that could not be explained by the independent variables in the model. The model summary shows an acceptable goodness of fit and the Durbin-Watson test indicates a lack of autocorrelation.

Table 5. Summary of error correction model (ECM).

\begin{tabular}{c|c|c|c|c}
\hline Variable & Coefficient & Std. Error & t-Statistic & Prob. \\
\hline $\mathrm{C}$ & 0.006570 & 0.009484 & 0.692707 & 0.4954 \\
\hline $\mathrm{D}$ & 0.001632 & 0.001661 & 0.982656 & 0.3360 \\
\hline $\mathrm{D}(\mathrm{LDRG})$ & -0.030912 & 0.039280 & -0.786961 & 0.4393 \\
\hline $\mathrm{D}(\mathrm{LCT} A \mathrm{X})$ & 0.116888 & 0.055070 & 2.122540 & 0.0448 \\
\hline $\mathrm{D}(\mathrm{LEXD})$ & -0.012965 & 0.013661 & -0.948984 & 0.3525 \\
\hline $\mathrm{D}(\mathrm{LGCEXP})$ & 0.026214 & 0.022489 & 1.165627 & 0.2557 \\
\hline $\mathrm{D}(\mathrm{LGFD})$ & -0.009828 & 0.008285 & -1.186337 & 0.2476 \\
\hline $\mathrm{D}(\mathrm{LPD})$ & -0.007713 & 0.016782 & -0.459605 & 0.6501 \\
\hline $\mathrm{ECM}(-1)$ & -0.918408 & 0.262035 & -3.504912 & 0.0019 \\
\hline $\mathrm{R}-\mathrm{square}$ & 0.737051 & - & - & - \\
\hline
\end{tabular}

Table 4 shows the short-run analysis of the relationship between fiscal policy and banking system stability in Nigeria between 1985 and 2019 using an error correction mechanism (ECM). The main variable of interest is 
government tax, which showed a positive significance beyond the 0.05 level of confidence. This implies that its importance is critical to the overall realignment and speed of adjustment of the variables in a parsimonious order. The result of the short-run analysis shows that current account deficit, consumption tax and government capital expenditure have a positive relationship with banking system stability; capital adequacy ratio showed an insignificant but positive relationship. This implies that an increase in current account deficit, consumption tax and government capital expenditure has a positive impact on banking system stability. This is understandable because these three variables directly affect the consumption, investment and savings culture of the citizens, which also has direct impact on banks' intermediation activities and their role in the economy. Similarly, an increase or decrease in the noted variables is critical to business growth. This also has a direct impact on banks' performance, liquidity and profitability. On the other hand, debt growth, external debt, government funding and public debt have a negative impact on capital adequacy ratio. This conforms with expectation because debt growth and external debt have little or no direct effect on domestic banks in Nigeria, as fiscal deficit and external debt are financed with external loans, thus they will not have a direct positive effect on banks when they are financed with loans from domestic banks or sources.

The parsimonious error correction model result in Table 5 shows an $\mathrm{R}^{2}$ of about $73.7 \%$ that indicates a better goodness of fit, so we can confirm that there is a strong relationship between each of the independent variables used and the dependent variable. Thus, it shows that $73.7 \%$ of the variation is explained by all the variables employed in the model, leaving $26.3 \%$ attributable to the white noise error term.

\section{CONCLUSION}

This sub-section draws conclusions from the summary of the regression analysis, which used cointegration and ordinary least squares analysis, culminating with the error correction model (ECM). The results with regard to the effect of fiscal policy on banking system stability in Nigeria was based on data from 1985 to 2019 and spanned across the periods before, during and after the Structural Adjustment Programme (SAP) using fiscal policy instruments. The results revealed that the government's fiscal policies significantly affect banking system stability in Nigeria both positively and negatively, and directly and indirectly. The indirect effects are through debt growth, external debt and tax, which affect capital inflows, foreign investment, foreign business partnerships, etc., and the direct effects are through government funding, government capital expenditure, consumption tax, and other government spending. These funds are usually expended through the domestic banks as payments to individuals (contractors, investors), corporate bodies and other government agencies. Thus, the study rejected the null hypothesis of the non-existence of an association between fiscal policies and banking system stability in Nigeria and accepted the alternative hypothesis that states that fiscal policy significantly impacts banking system stability in Nigeria.

\section{RECOMMENDATIONS}

Based on the above conclusions, the study recommendations are as follows: (i) the government should increase its expenditure in the domestic economy, to the right investible ends, and focus on welfare benefits for the population and on long-term benefits for the economic objectives of the country; (ii) the management of banks should be proactive to ensure that fiscal sectoral policies bring the desired benefits to the banking system by the way they commit the government to the development and involvement in the system. In this way, policies such as the Treasury Single Account (TSA) would not need to exist in the first place; (iii) appropriate checks should be put in place by the government to avoid excessive borrowing across the various levels of government that will lead to crowding out of the private sector in credit markets; (iv) the government should ensure that whatever borrowings are undertaken are channeled towards productive segments of the economy to enhance sustainable repayment of debt; (v) the government should adhere to the terms of any credit contracts they have with the banks. Finally, the 
Central Bank must be proactive at controlling the possibility of the banking system preferring to lend to the public sector over the private sector.

Funding: This study received no specific financial support.

Competing Interests: The authors declare that they have no competing interests.

Acknowledgement: All authors contributed equally to the conception and design of the study.

\section{REFERENCES}

Adegoriola, A. E. (2018). An empirical analysis of effectiveness of monetary and fiscal policy instruments in stabilizing economy: Evidence from Nigeria. Social Sciences, 7(3), 133-140. Available at: https://doi.org/10.11648/j.ss.20180703.14.

Aero, O., \& Ogundipe, A. (2018). Fiscal deficit and economic growth in Nigeria: Ascertaining a feasible threshold. International Journal of Economics and Financial Issues, 8(3), 296-306. Available at: https://doi.org/10.2139/ssrn.2861505.

Agu, S., Okwo, I., Ugwunta, O., \& Idike, A. (2015). Fiscal policy and economic growth in Nigeria: Emphasis on various components of public expenditure. Sage Open, 5(4), 2158244015610171. Available at: https://doi.org/10.1177/2158244015610171.

Alińska, A. (2016). Fiscal sustainability and financial stability-challenges and experiences during a time of financial crisis. Structural Changes in Public Sector Units, $70(5), 13-24$.

Alqahtani, F., \& Mayes, D. (2018). Financial stability of Islamic banking and the global financial crisis: Evidence from the Gulf Cooperation Council. Economic Systems, 42(2), 346-360. Available at: https://doi.org/10.1016/j.ecosys.2017.09.00 1.

Chukwudi, O., \& Henry, J. (2020). Monetary policy and financial stability in the Nigerian banking industry. International Journal of Financial Research, 11(1), 82-114. Available at: https://doi.org/10.5430/ijfr.v1 1n 1 p82.

Dumičić, M. (2019). Linkages between fiscal policy and financial (in) stability. Journal of Central Banking Theory and Practice, 8(1), 97-109. Available at: https://doi.org/10.2478/jcbtp-2019-0005.

Itoro, U.-A. (2017). Fiscal policy measures and macroeconomic stability in Nigeria. North Asian International Research Journal of Social Science \& Humanities, 3(5), 1-22.

Knowles, S., Phillips, G., \& Lidberg, J. (2017). Reporting the global financial crisis: A longitudinal tri-nation study of mainstream financial journalism. Journalism Studies, 18(3), 322-340. Available at: https://doi.org/10.1080/1461670X.2015.1058182.

Matallah, A., \& Matallah, S. (2017). Does fiscal policy spur economic growth? Empirical evidence from Algeria. Theoretical and Applied Economics, 24(3), 125-146.

Neem, M. (2019). The impact of fiscal policy on economic growth: Panel data analysis. Pakistan Business Review, 20(2), 465-476.

Okoye, L. U., Evbuomwan, G. O., Modebe, N. J., \& Ezeji, F. N. (2016). Macroeconomic performance and government fiscal deficits-Evidence from Nigeria. Nigerian Journal of Management Technology ङ Development, 7(2), 1-8.

Thach, N., Oanh, T., \& Chuong, H. (2018). The interaction between fiscal policy, macroprudential policy and financial stability in Vietnam-an application of structural equation modeling. Structural Changes and Their Econometric Modeling, 4(2), 275288. Available at: https://doi.org/10.1371/journal.pone.0118917.

Trading Economics. (2020). Nigeria fiscal expenditure. Retrieved from https://tradingeconomics.com/nigeria/fiscalexpenditure. [Accessed June 29, 2020].

Tule, M. K., Onipede, S. F., \& Ebuh, G. U. (2020). Monetary and fiscal policy mix in a small open economy: Evidence from Nigeria. Scientific African, 8, e00346. Available at: https://doi.org/10.1016/j.sciaf.2020.e00346.

Ubi-Abai, I., \& Bosco, I. (2017). Fiscal policy and macroeconomic stability in Nigeria. North Asian International Research Journal of Social Science and Humanities, 3(5), 3-23.

Views and opinions expressed in this article are the views and opinions of the author(s), Asian Economic and Financial Review shall not be responsible or answerable for any loss, damage or liability etc. caused in relation to/arising out of the use of the content. 